Backfat fatty acid evolution in swine fed diets high in either cis-monounsaturated, trans, or n-...

Fontanillas, R;Barroeta, A;Baucells, M D;Guardiola, F Journal of Animal Science; Apr 1998; 76, 4; ProQuest pg. 1045

\title{
Backfat Fatty Acid Evolution in Swine Fed Diets High in Either cis-Monounsaturated, trans, or (n-3) Fats ${ }^{1}$
}

\author{
R. Fontanillas*, A. Barroeta ${ }^{*, 2}$, M. D. Baucells*, and F. Guardiola ${ }^{\dagger}$
}

*U. D. Nutrició i Alimentació Animal, Facultat de Veterinària, UAB, E-08193 Bellaterra, Spain and U. D. Nutrició i Bromatologia, Facultat de Farmàcia, UB, E-08028 Barcelona, Spain

\begin{abstract}
To evaluate the effects of dietary fats on the evolution of the fatty acid profile of swine backfat, 30 castrated Landrace $\times$ Duroc pigs averaging $26 \mathrm{~kg}$ were assigned three diets with $4 \%$ added pomace oil ( $\mathrm{O})$, hydrogenated fat $(\mathrm{H})$, or linseed oil (L). Subcutaneous fat samples were taken from biopsies at $0,17,31$, and $60 \mathrm{~d}$, and at $24 \mathrm{~h}$ postmortem when pigs averaged $95 \mathrm{~kg}$ live weight at $82 \mathrm{~d}$ on trial. On d 17, saturated fatty acid (SFA) content was $2 \%$ lower for the $\mathrm{O}$ diet than for $\mathrm{H}$ and $\mathrm{L}(P<.089)$. There was a linear increase in SFA at a monthly rate of $2 \%$ in the three diets. The increase was mainly due to 18:0; palmitic acid percentages showed no variation. Pigs fed the $\mathrm{O}$ diet experienced exponential increases in monounsaturated fatty acids (MUFA), especially
\end{abstract}

until d $17(P<.001)$. In pigs fed the $\mathrm{H}$ or L diets, MUFA contents decreased at a monthly rate of $2.40 \%$, and the same happened with oleic acid contents. Diets rich in $(n-3)(\mathrm{L})$ and trans-fatty acids $(\mathrm{H})$ caused exponential increases in swine backfat contents of total $(n-3)$ and total trans, respectively. At d $31(P<$ .001 ), 72 to $73 \%$ of the maximum contents had been reached. Contents for $20: 3(n-3), 20: 5(n-3)$, and 22 : $5(n-3)$ follow a pattern similar to that of their precursor 18:3(n-3), showing an exponential increase in pigs fed the $\mathrm{L}$ diet, and contents for $\mathrm{H}$ and $\mathrm{O}$ treatments were lower $(P<.001)$. The three diets caused a linear decrease in $(n-6)$ fatty acid contents throughout the 82 -d trial.

Key Words: Pigmeat, Fatty Acids, Trans-Fatty Acids

(c)1998 American Society of Animal Science. All rights reserved.

J. Anim. Sci. 1998. 76:1045-1055

\section{Introduction}

Research on swine nutrition has shown that it is possible to increase the contents of monounsaturated fatty acids (MUFA), such as oleic acid, and polyunsaturated fatty acids, such as linolenic acid and the ( $n$-3) fatty acids series, depending on the type of fat added to the diet (St. John et al., 1987; Hertzman et al., 1988; Romans et al., 1995a).

Although the overall evolution of the main fatty acid profile of pigs has been documented (Irie and Sakimoto, 1992; Camoes et al., 1995), it is still necessary to thoroughly research all fatty acids, to determine their cis or trans configuration and to discover their relationships. The goal of this experiment was to study the evolution of fatty acid composition in pork backfat as a model of carcass fat

\footnotetext{
${ }^{1}$ The authors wish to acknowledge the skilled technical support of Olga Baños and financial assistance of the Spanish Government (CICYT ALI91-0991-002-02).

${ }^{2}$ To whom correspondence should be addressed: fax: (3) 581-2006; E-mail: IVPPO@cc.uab.es.

Received March 13, 1997.

Accepted September 26, 1997.
}

depots throughout the growing-finishing periods. Diets were supplemented with different fats: pomace oil (O), rich in cis-MUFA [oleic acid, 18:1(n-9)c]; hydrogenated oil $(\mathbf{H})$, rich in trans-monounsaturated fatty acids ('TFA) (elaidic acid, 18:1[n-9]t); and linseed oil ( L), rich in ( $n-3)$ fatty acids (linolenic acid, 18:3[n-3]). A second goal was to determine the time needed to cause changes in the fatty acid composition. This could be of major interest to production, because it could pave the way to obtaining products rich in specific fatty acids.

\section{Materials and Methods}

Animals and Experimental Diets. Castrated males $(\mathrm{n}=30)$ of a commercial Landrace $\times$ Duroc $\left(\mathrm{F}_{1}\right)$ cross were distributed uniformly according to their weight and original litter in three experimental treatments. The barrows were housed in groups of five pigs (two groups in each treatment) and fed the same basal diet of corn, barley, and soybean meal (NRC, 1988; basal diet, Tables 1 and 2 ) with a $4 \%$ supplement of three fat sources: $\mathrm{O}, \mathrm{H}$, or $\mathrm{L}$ (Table 2). In a previous, $18-d$ period of adaptation, pigs were fed the same diet 
Table 1. Pre-experimental and basal diet composition (as fed)

\begin{tabular}{|c|c|c|}
\hline Item & $\begin{array}{l}\text { Pre-experimen- } \\
\text { tal diet }\end{array}$ & Basal diet \\
\hline & - $\%$ & 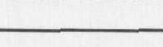 \\
\hline \multicolumn{3}{|l|}{ Ingredient } \\
\hline Wheat & 21.00 & 27.76 \\
\hline Barley & 39.23 & 34.00 \\
\hline Wheat bran & 15.00 & 15.00 \\
\hline Soybean meal ( $47 \%$ CP) & 15.44 & 13.94 \\
\hline Meat meal (50\% CP) & 2.00 & 2.00 \\
\hline Added fat & 4.00 & $4.00^{\mathrm{a}}$ \\
\hline Salt & .52 & .50 \\
\hline Calcium carbonate & .80 & .74 \\
\hline Dicalcium phosphate & 1.15 & 1.20 \\
\hline Methionine (98\%) & .02 & .02 \\
\hline Lysine $(78 \%)$ & .22 & .22 \\
\hline Vitamin and mineral $^{\mathrm{b}}$ & .62 & .62 \\
\hline \multicolumn{3}{|l|}{ Nutrient profile } \\
\hline Crude energy, $\mathrm{kcal} / \mathrm{kg}^{\mathrm{c}}$ & $4,324.00$ & $4,210.1$ \\
\hline Digestible energy, $\mathrm{kcal} / \mathrm{kg}^{\mathrm{d}}$ & $3,368.00$ & $3,279.3$ \\
\hline Dry matter, $\%^{\mathrm{c}}$ & 90.13 & 89.45 \\
\hline Crude protein, $\%^{\mathrm{c}}$ & 18.63 & 16.80 \\
\hline Fiber, $\%^{\mathrm{c}}$ & 3.34 & 4.69 \\
\hline Ether extract, $\%^{\mathrm{c}}$ & 6.86 & 6.24 \\
\hline Ash, $\%^{\mathrm{c}}$ & 5.35 & 6.06 \\
\hline Lysine, $\%^{\mathrm{d}}$ & .95 & .95 \\
\hline Methionine, $\%^{\mathrm{d}}$ & .29 & .29 \\
\hline Methionine + cystine, $\%^{\mathrm{d}}$ & .59 & .59 \\
\hline Calcium, $\%^{\mathrm{d}}$ & .80 & .80 \\
\hline Phosphorus, $\%^{\mathrm{d}}$ & .63 & .63 \\
\hline
\end{tabular}

a Fat added as pomace oil, hydrogenated oil, or linseed oil.

bSupplied per kilogram of total diet: vitamin A: $12,000 \mathrm{IU}$; vita$\min \mathrm{D}_{3}: 2,400 \mathrm{IU}$; vitamin $\mathrm{E}: 30 \mathrm{mg}$; vitamin $\mathrm{K}_{3}: 2 \mathrm{mg}$; riboflavin: 3 $\mathrm{mg}$; vitamin $\mathrm{B}_{6}: 5 \mathrm{mg}$; vitamin $\mathrm{B}_{12}: 11 \mu \mathrm{g}$; biotin: $.5 \mathrm{mg}$; niacin: 40 $\mathrm{mg}$; choline chloride: $66 \mathrm{mg}$; pantothenic acid: $25 \mathrm{mg}$; folic acid: .5 mg; Fe: 80 mg; Cu: 8 mg; Zn: 40 mg; Mn: 5.9 mg; Se: .14 mg; I: .33 $\mathrm{mg}$

${ }^{\mathrm{c}}$ Analyzed (AOAC, 1990).

${ }^{\mathrm{d}}$ Estimated.

(Tables 1 and 2). The experiment began when the pigs were approximately $80 \mathrm{~d}$ old and $26 \pm 4.3 \mathrm{~kg}$ in live weight. After 82 a on the experimental diets, the pigs were slaughtered at a live weight of $95.56 \pm 2.16$ $\mathrm{kg}$, and carcasses were weighed and evaluated. A FatO-Meter (SFK Ltd., Denmark) was used to measure carcass fat thickness $6 \mathrm{~cm}$ from the midline at two points: between the third and the fourth ribs, and at the last rib. Animals were given ad libitum access to feed throughout the experiment. Animal weight and feed consumption were recorded with the same periodicity that biopsies were taken, and at the end of the study. The experiment was carried out at the experimental unit of the Faculty of Veterinary Science of the Universitat Autònoma de Barcelona under adequate conditions of temperature, light, and ventilation.

Biopsy Procedures. Four samples from the area between the cranial angle of the scapula and the spinous process of the fourth thoracic vertebra were taken from six pigs from each diet (the pigs closest to
Table 2. Fatty acid composition of pre-experimental and experimental diets containing pomace oil $(\mathrm{O})$, hydrogenated oil $(\mathrm{H})$, and linseed oil $(\mathrm{L})$

\begin{tabular}{|c|c|c|c|c|}
\hline Fatty acid ${ }^{a}$ & $\begin{array}{c}\text { Pre- } \\
\text { experimental }\end{array}$ & $\mathrm{O}$ & $\mathrm{H}$ & $\mathrm{L}$ \\
\hline $10: 0$ & .09 & .03 & .06 & .05 \\
\hline $12: 0$ & .11 & .05 & .06 & .08 \\
\hline $14: 0$ & 1.15 & .33 & .30 & .40 \\
\hline $15: 0$ & .14 & .10 & .09 & .12 \\
\hline $16: 0$ & 18.00 & 14.20 & 16.27 & 14.09 \\
\hline $16: 1(n-7) \mathrm{t}$ & .13 & .04 & .05 & .05 \\
\hline $16: 1(n-9)$ & .23 & .16 & .07 & .10 \\
\hline $16: 1(n-7)$ & 1.77 & .63 & .28 & .32 \\
\hline $17: 0$ & .31 & .19 & .14 & .19 \\
\hline $18: 0$ & 7.40 & 3.88 & 10.27 & 4.65 \\
\hline $18: 1(n-9) \mathrm{t}$ & .97 & .76 & 19.56 & .48 \\
\hline $18: 1(n-9)$ & 30.69 & 54.34 & 25.88 & 22.72 \\
\hline $18: 1(n-7)$ & 2.16 & 1.66 & 2.10 & 1.35 \\
\hline $18: 2(n-6) \mathrm{t}$ & .25 & .16 & .83 & .13 \\
\hline $18: 2(n-6)$ & 31.38 & 19.68 & 20.40 & 27.58 \\
\hline $18: 3(n-6)$ & .03 & .03 & .03 & .53 \\
\hline $18: 3(n-3)$ & 2.51 & 1.72 & 2.57 & 25.79 \\
\hline $20: 0$ & .36 & .41 & .40 & .26 \\
\hline $20: 1(n-9)$ & .90 & .50 & .37 & .55 \\
\hline $20: 2(n-6)$ & .42 & .88 & .09 & .15 \\
\hline $20: 3(n-6)$ & .07 & .00 & .00 & .06 \\
\hline $20: 3(n-3)$ & .18 & .00 & .00 & .16 \\
\hline $20: 4(n-6)$ & .01 & .00 & .00 & .06 \\
\hline $20: 5(n-3)$ & .23 & .06 & .04 & .22 \\
\hline $22: 4(n-6)$ & .09 & .02 & .02 & .06 \\
\hline $22: 5(n-3)$ & .13 & .12 & .09 & .18 \\
\hline $22: 6(n-3)$ & .30 & .07 & .05 & .11 \\
\hline SFA & 27.55 & 19.18 & 27.58 & 19.80 \\
\hline MUFA & 35.75 & 57.28 & 28.69 & 24.98 \\
\hline PUFA & 35.35 & 22.58 & 23.28 & 54.58 \\
\hline PUFA/SFA & 1.28 & 1.28 & 0.85 & 2.82 \\
\hline TFA & 1.35 & 0.96 & 20.44 & .63 \\
\hline$(n-3)$ & 3.35 & 1.97 & 2.75 & 26.46 \\
\hline$(n-6)$ & 32.00 & 20.61 & 20.54 & 28.44 \\
\hline$(n-6) /(n-3)$ & 9.55 & 10.38 & 7.74 & 1.14 \\
\hline
\end{tabular}

aSFA = saturated fatty acids, MUFA = monounsaturated fatty acids, PUFA $=$ polyunsaturated fatty acids, and TFA $=$ transmonounsaturated fatty acids.

the average weight). To do so, a Czech gun with an adapted cannula (PPB-2 Biotech, Nitra, Slovakia) was used. Measurements were always taken from the whole fat thickness. All necessary measures were taken to prevent animal discomfort during and after all processes.

The first biopsy was performed at the end of the adaptation period ( $\mathrm{d} 0$ ). Three of the remaining four biopsies were carried out at $17(37 \pm 5.5 \mathrm{~kg}$ live weight), 31 ( $50 \pm 6.0 \mathrm{~kg}$ live weight), and $60 \mathrm{~d}(78 \pm$ $6.70 \mathrm{~kg}$ live weight) from the beginning of the experiment. The last samples were taken at the end of the experiment $(82 \mathrm{~d})$ at $24 \mathrm{~h}$ after death in the slaughter facilities. All samples were stored at $-20^{\circ} \mathrm{C}$.

Fatty Acid Profile Determination. Fatty acid profiles in experimental diets and in the samples were determined by lipid extraction (Folch et al., 1957) and 
Table 3. Saturated fatty acids (\%) of backfat samples from swine fed diets containing pomace oil $(\mathrm{O})$, hydrogenated oil $(\mathrm{H})$, and linseed oil $(\mathrm{L})$

\begin{tabular}{|c|c|c|c|c|c|}
\hline \multirow{2}{*}{$\begin{array}{l}\text { Fatty acid and } \\
\text { treatment }^{\mathrm{a}}\end{array}$} & \multicolumn{5}{|c|}{ Day } \\
\hline & 0 & 17 & 31 & 60 & 82 \\
\hline \multicolumn{6}{|l|}{ Total SFA } \\
\hline $\mathrm{O}$ & 32.44 & 30.96 & 32.31 & 34.20 & $35.53^{\mathrm{d}}$ \\
\hline $\mathrm{H}$ & 30.38 & 34.42 & 34.61 & 35.96 & $39.29^{c}$ \\
\hline $\mathrm{L}$ & 31.10 & 34.71 & 33.86 & 35.60 & $37.99^{\mathrm{d}}$ \\
\hline SE & .976 & 1.23 & .827 & .965 & .964 \\
\hline$P$ & .344 & .089 & .167 & .371 & .046 \\
\hline \multicolumn{6}{|l|}{ 18:0 } \\
\hline $\mathrm{O}$ & 8.24 & 8.48 & 9.73 & 10.58 & $11.69^{d}$ \\
\hline $\mathrm{H}$ & 7.48 & 10.25 & 10.98 & 12.26 & $14.60^{c}$ \\
\hline $\mathrm{L}$ & 7.91 & 10.62 & 10.60 & 12.15 & $14.19^{\mathrm{cd}}$ \\
\hline $\mathrm{SE}$ & .592 & .630 & .484 & .526 & .677 \\
\hline$P$ & .288 & .065 & .207 & .051 & .018 \\
\hline \multicolumn{6}{|l|}{$16: 0$} \\
\hline $\mathrm{O}$ & 21.25 & 20.29 & 20.64 & 21.67 & 21.99 \\
\hline $\mathrm{H}$ & 20.54 & 21.92 & 21.53 & 21.65 & 22.65 \\
\hline $\mathrm{L}$ & 20.74 & 21.69 & 21.15 & 21.49 & 22.05 \\
\hline SE & .493 & .677 & .486 & .571 & .432 \\
\hline$P$ & .592 & .215 & .445 & .965 & .504 \\
\hline \multicolumn{6}{|l|}{$20: 0$} \\
\hline $\mathrm{O}$ & .13 & .12 & $.14^{\mathrm{d}}$ & $.16^{\mathrm{d}}$ & $.23^{\mathrm{d}}$ \\
\hline $\mathrm{H}$ & .11 & .15 & $.16^{\mathrm{c}}$ & $.16^{\mathrm{d}}$ & $.28^{\mathrm{c}}$ \\
\hline $\mathrm{L}$ & .15 & .15 & $.18^{\mathrm{c}}$ & $.18^{c}$ & $.27^{\mathrm{cd}}$ \\
\hline $\mathrm{SE}$ & .011 & .015 & .010 & .001 & .012 \\
\hline$P$ & .091 & .196 & .023 & .025 & .023 \\
\hline \multicolumn{6}{|l|}{ SFA $\mathrm{m}^{\mathrm{b}}$} \\
\hline $\mathrm{O}$ & 2.24 & 2.07 & 1.80 & 1.80 & $1.63^{\mathrm{cd}}$ \\
\hline $\mathrm{H}$ & 2.25 & 2.10 & 1.94 & 1.90 & $1.77^{\mathrm{c}}$ \\
\hline $\mathrm{L}$ & 2.31 & 2.25 & 1.93 & 1.79 & $1.48^{\mathrm{d}}$ \\
\hline SE & .079 & .099 & .060 & .064 & .063 \\
\hline$P$ & .799 & .421 & .225 & .410 & .030 \\
\hline
\end{tabular}

subsequent esterification with sodium methylate(.5 $N)$ and $20 \%$ boron trifloride-methanol complex in methanolic solution (Guardiola et al., 1994). The fatty acid methyl esters were separated on a Perkin Elmer Autosystem gas chromatograph equipped with a silica pre-column (.25 mm i.d. and $2.5 \mathrm{~m}$ long) with deactivated cyanopropyl/phenyl/methyl silicone and a fused silica capillary column $(.25 \mathrm{~mm}$ i.d. and $50 \mathrm{~m}$ long) with a $.2-\mu \mathrm{m}$ internal coating of cyanopropyl silicone (CP-Sil 88, Chrompak). The conditions used were as follows: $11.2 \mathrm{~min}$ at $177^{\circ} \mathrm{C}$, from $177^{\circ} \mathrm{C}$ to $225^{\circ} \mathrm{C}$ at $7^{\circ} \mathrm{C} / \mathrm{min}$ and $11 \mathrm{~min}$ at $225^{\circ} \mathrm{C}$. The injector temperature was $270^{\circ} \mathrm{C}$. Detector temperature was $300^{\circ} \mathrm{C}$. The split ratio was $1: 30$. Volume injected was .2 to $.5 \mu \mathrm{L}$. Identification was made by comparison with retention times of the corresponding pure standards and by co-chromatography as described by Guardiola et al. (1994). Quantification was carried out through area normalization, expressing the results as percentage of each fatty acid relative to total fatty acids. A combined value is given for the trans isomers of linoleic acid, 18:2(n-6) cis-trans, 18:2(n-6) transtrans, and 18:2(n-6) trans-cis, because they were not entirely separated under these chromatographic conditions.

Statistical Analysis. Fatty acid proportions in each biopsy were subjected to an analysis of variance using the GLM procedure of SAS (1994). For statistically significant differences $(P<.05)$, means were compared using the LSD method of SAS. Finally, the evolution of fatty acids was studied by means of a regression analysis to either a linear or an exponential equation, whichever fit best. The exponential equation, following Cole (1973), was of the type $y=a-b$ $\mathrm{e}^{-\mathrm{ct}}$, where $\mathrm{a}$ is the maximum level throughout the experimental period, $(a-b)$ is the initial percentage, and $c$ is the daily accretion fractional rate $\left(\mathrm{d}^{-1}\right)$. Functions resulting in straight lines were subjected to a test of slope comparison.

\section{Results and Discussion}

Dietary treatments did not affect any measured production of carcass traits. Tables 3 to 5 show fatty acids percentages in each biopsy and a comparison among diets in each extraction. Figures 1 to 5 display 


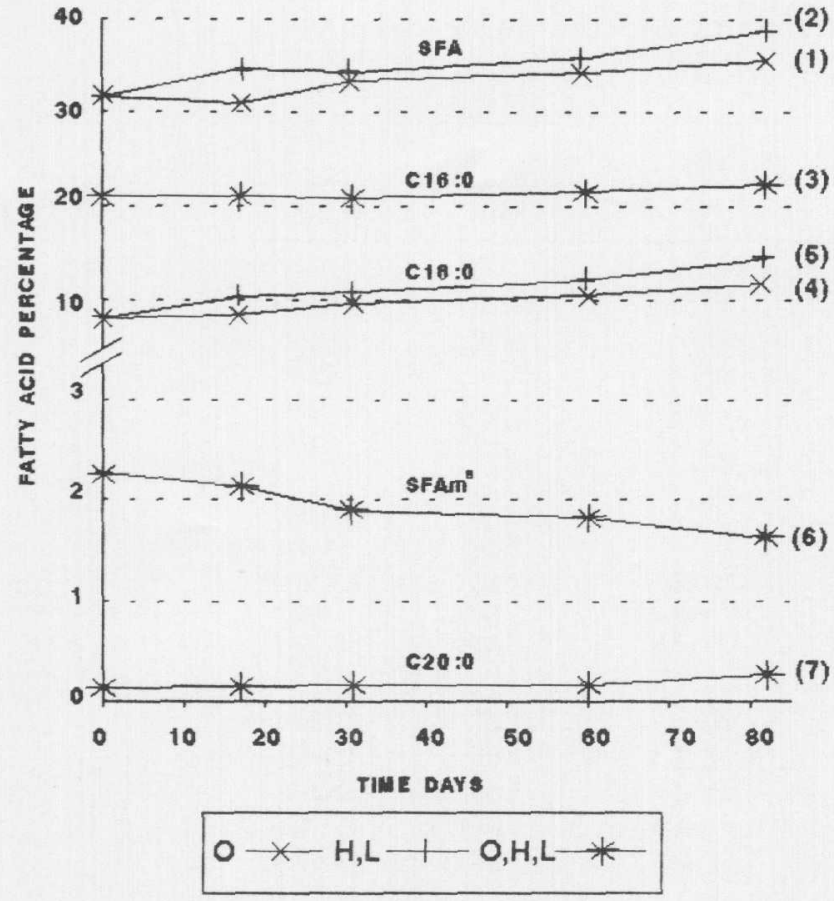

Figure 1. Saturated fatty acids (SFA), 16:0, 18:0, and SFAm* percentage evolution ( 1 to 7 : corresponding equations in Table 6). *SFAm: 10:0 + 12:0 + 14:0 + 15:0 + 17:0; O: pomace oil; $\mathrm{H}$ : hydrogenated oil; L: linseed oil.

the evolution in the backfat fatty acid profile for the

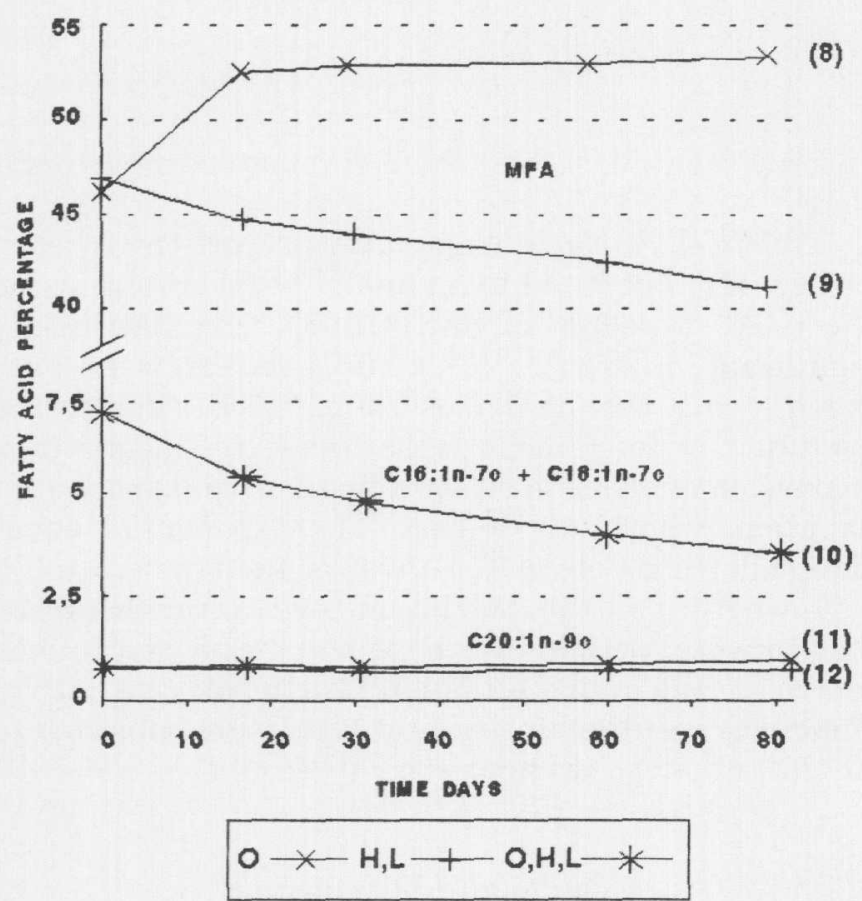

Figure 2. Monunsaturated fatty acids (MUFA) and MUFA derivatives percentage evolution (8 to 12: corresponding equations in Table 6). O: pomace oil; $\mathrm{H}$ : hydrogenated oil; L: linseed oil.

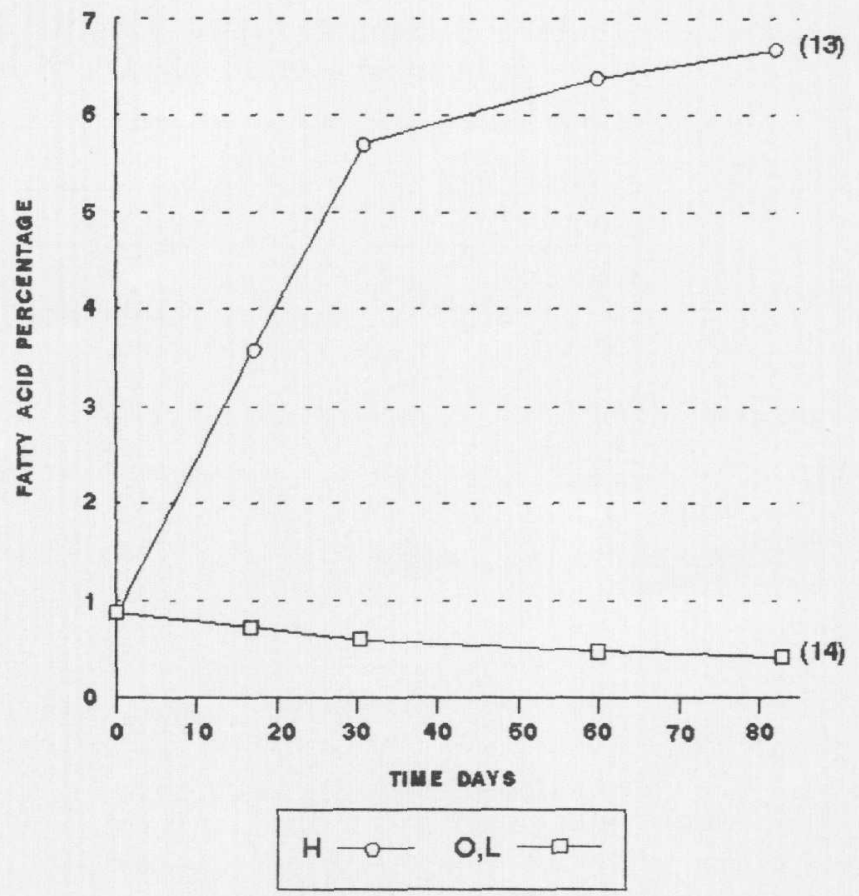

Figure 3. Total trans fatty acids percentage evolution (13-14: corresponding equations in Table 7). O: pomace oil; H: hydrogenated oil; L: linseed oil.

whole experimental period ( $82 \mathrm{~d}$ ). Adjusted functions for each case are to be found in Tables 6 to 8 . Within each fatty acid family, minor fatty acids with similar evolution have been grouped.

Only a few studies have been published on the evolution in the contents of the main fatty acids in the lipid deposits of pigs. Some researchers slaughtered pigs at certain periods (Koch et al., 1968; Romans et al., 1995b), and others (Irie and Sakimoto, 1992; Camoes et al., 1995; the present study) took in vivo samples.

As expected, after feeding the pigs the same diet for $18 \mathrm{~d}$ before the start of the trial, there were no significant differences $(P>.05)$ according to diet. In general, at the end of the trial, increases were noticed in the contents of the main fatty acid characteristic of each diet. Thus, the percentage for MUFA $(P<.001)$ found in pigs fed pomace oil was higher than in pigs fed hydrogenated oil or linseed oil ( $\mathrm{O}, 53.36$ vs $\mathrm{H}$, 41.90 and L, 40.12\%; Table 4). These differences clearly mirror what happened to the main fatty acid, oleic acid; (18:1[n-9], (O, 48.39 vs $\mathrm{H}, 36.90$ and $\mathrm{L}$, $36.02 \% ; P<.001)$.

Pigs fed the $\mathrm{H}$ diet showed a higher proportion $(P<$ $.001)$ of trans-fatty acids $(H, 6.67$ vs $\mathrm{O}, .41$ and $\mathrm{L}$, $.45 \%)$, reflecting the higher percentage in elaidic acid $(18: 1[n-9] \mathrm{t})$, which is the main trans fatty acid $(\mathrm{H}$, 5.88 vs $\mathrm{O}, .30$ and $\mathrm{L}, .34 \% ; P<.001)$. Pigs fed the $\mathrm{L}$ diet had the highest percentage $(P<.001)$ in $(n-3)$ ( $\mathrm{L}, 10.58$ vs $\mathrm{O}, 1.17$ and $\mathrm{H}, 1.96 \%$; Table 5 ), due to the rise $(P<.001)$ in linolenic acid $(\mathrm{L}, 9.16$ vs $\mathrm{O}, .99$ and $H, 1.61 \%$ ). At the end of the trial, pigs fed the $L$ 


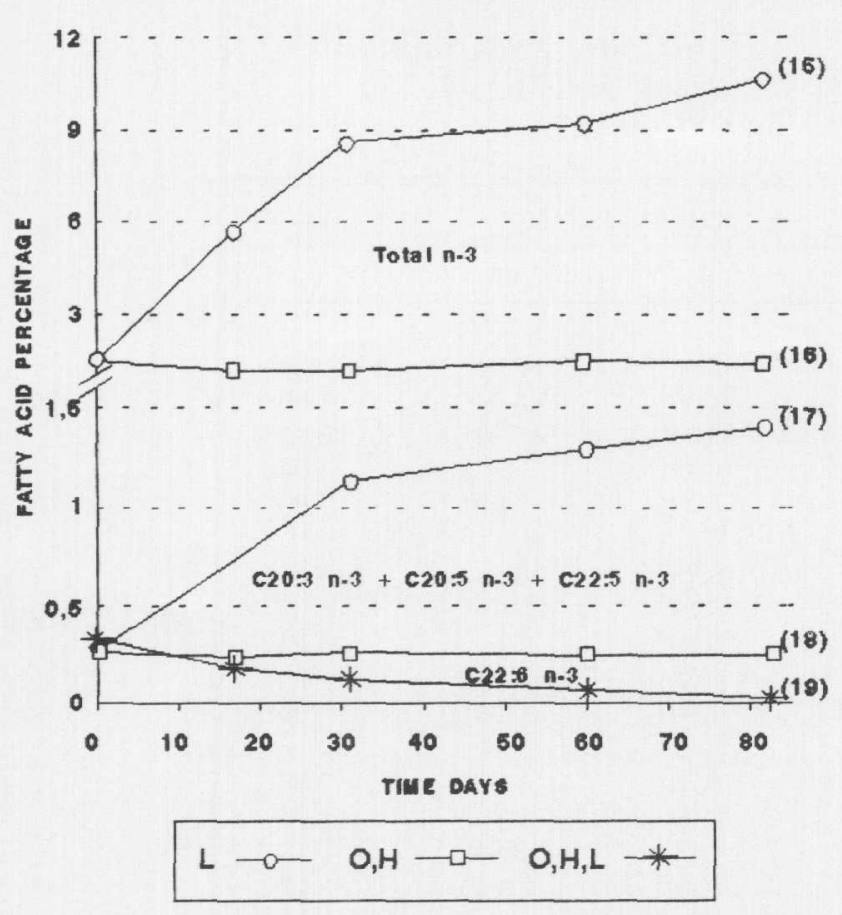

Figure 4. (n-3) Fatty acids percentage evolution (15 to 19: corresponding equations in Table 8). O: pomace oil; $\mathrm{H}$ : hydrogenated oil; L: linseed oil.

diet also had higher proportions $(P<.001)$ of 20 : $5(n-3)(\mathrm{L}, .06$ vs $\mathrm{O}, .01$ and $\mathrm{H}, .02 \%)$ and of $22: 5(n-$ $3)(\mathrm{L}, .14$ vs $\mathrm{O}, .04$ and $\mathrm{H}, .07 \%)$, but not $(P>.05)$ of $22: 6(n-3)$ (L, .02; O, .01; and $\mathrm{H}, .02 \%)$.

Saturated Fatty Acids. The evolution of overall SFA contents, displayed in Figure 1 (Table 6 ) reflects the results for palmitic (16:0) and (18:0) stearic acids. Differences in SFA proportions among diets were already noticeable $(P<.089)$ at trial d 17 when, compared with data from the $\mathrm{O}$ diet, the feeding of $\mathrm{H}$ and $\mathrm{L}$ diets resulted in a $2 \%$ increase in SFA contents. Later incorporations remained at a linear monthly rate of $2 \%$ for the three diets. These incorporations are mainly due to 18:0, because palmitic acid did not increase throughout the period.

The proportions of other saturated fatty acids (SFA) were small and showed minimal variations throughout the trial. In the three diets, minor fatty acids $(10: 0+12: 0+14: 0+15: 0+17: 0 ;$ Figure 1$)$ decreased (hence, the negative slope, -.008). The exception is 20:0 (Table 6, Eq. 7), which can come from a dietary origin or be the result of endogenous synthesis from stearic acid. The contents of 20:0 and its precursor increased similarly in the three diets throughout the trial.

There are very few studies on the effects of using different diets on SFA incorporation rates and levels over time. Miller et al. (1990) and St. John et al. (1987) observed a decrease in backfat saturation levels when using diets heavily supplemented with fat (10 or $20 \%$ ), compared to results from diets with no

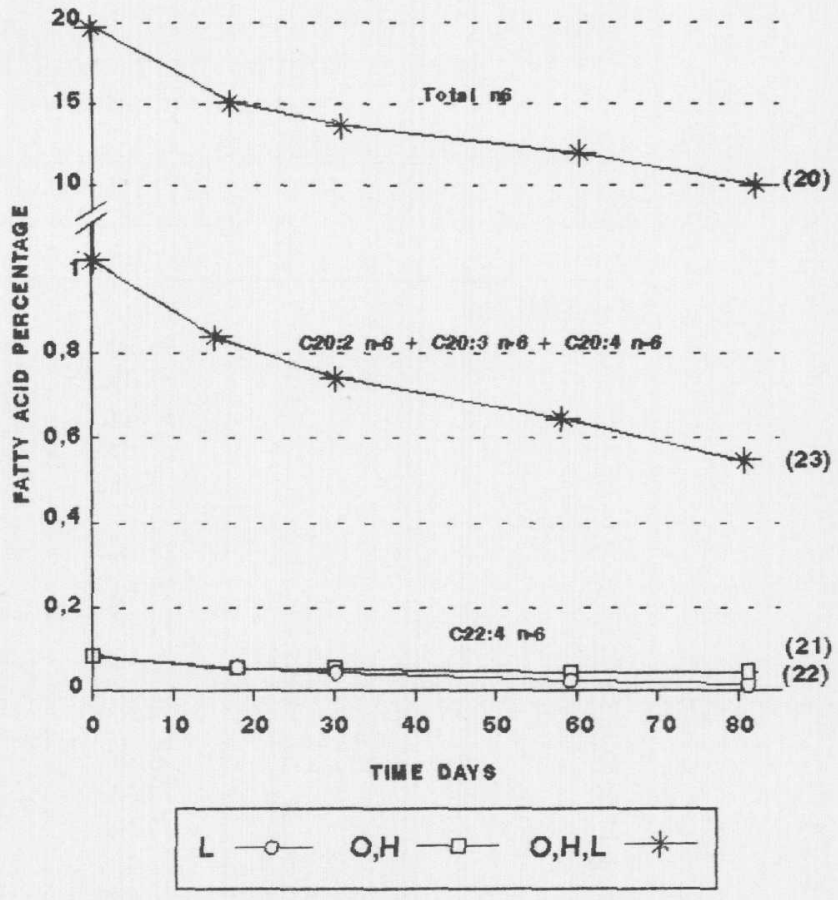

Figure 5. (n-6) Fatty acids percentage evolution (20 to 23: corresponding equations in Table 8). O: pomace oil; $\mathrm{H}$ : hydrogenated oil; L: linseed oil.

fat supplement. However, high levels of dietary 18:1 have been effective in lowering the saturation levels of tissues. Thus, Miller et al. (1990) obtained lower percentages of $16: 0$ and 18:0 with diets rich $(80.9$, 72.10 , and $57.7 \%$ ) in $18: 1$ than with diets low $(45.3 \%)$ in it. Cava et al. (1997) have observed a decrease in 18:0 (9.71 vs $12.52 \%, P<.05)$ in muscle triglycerides, comparing a diet with $63.81 \%$ of $18: 1$ and $16.07 \%$ of $18: 2$ to a second diet with $24.07 \%$ of $18: 1$ and $47.30 \%$ of $18: 2$.

However, temporal variations are not conclusive, Romans et al. (1995b) used a diet with $15 \%$ linseeds and did not find significant changes after $28 \mathrm{~d}$. Leszcynski et al. (1992) used diets with added tallow or full-fat soybeans for 3 to $6 \mathrm{wk}$ and observed a decrease in saturation levels in 18:0, 16:0, and SFA. Wood (1984) found that, when using diets with fat supplements below 4\%, 18:0 contents increase throughout the life of pigs, whereas 16:0 contents tend to decrease. In our study, we concluded that 1) differences in SFA contents were noticeable at $17 \mathrm{~d} ; 2$ ) SFA contents increased above $5 \%$ throughout the trial, mainly because of endogenous synthesis of stearic acid; and 3 ) the values for 18:0 in pigs fed $H$ could be explained by the higher dietary levels. Differences between pigs fed $\mathrm{L}$ and those fed $\mathrm{O}$ could be due to different degrees of inhibition of the stearoyl-CoA desaturase activity by dietary polyunsaturated fatty acids (PUFA) (Waters et al., 1996) and 18: $1(n-9)$ (Klingenberg et al., 1995), respectively.

Cis-Monounsaturated Fatty Acids. The values for MUFA contents in pigs fed the $\mathrm{O}$ diet increased nearly 
Table 4. Cis-monounsaturated and trans-monunsaturated fatty acids profiles (\%) of backfat samples from swine fed diets containing pomace oil $(\mathrm{O})$, hydrogenated oil (H), and linseed oil (L)

\begin{tabular}{|c|c|c|c|c|c|}
\hline \multirow{2}{*}{$\begin{array}{l}\text { Fatty acid and } \\
\text { treatment }\end{array}$} & \multicolumn{5}{|c|}{ Day } \\
\hline & 0 & 17 & 31 & 60 & 82 \\
\hline \multicolumn{6}{|l|}{ Total MUFA } \\
\hline & 46.19 & $52.45^{\mathrm{b}}$ & $52.86^{b}$ & $52.94^{\mathrm{b}}$ & $53.36^{b}$ \\
\hline $\mathrm{H}$ & 47.35 & $46.13^{\mathrm{c}}$ & $44.38^{c}$ & $43.34^{\mathrm{c}}$ & $41.90^{\mathrm{c}}$ \\
\hline $\mathrm{L}$ & 46.34 & $43.27^{\mathrm{c}}$ & $41.50^{c}$ & $41.82^{\mathrm{c}}$ & $40.12^{\mathrm{c}}$ \\
\hline $\mathrm{SE}$ & .846 & .948 & .822 & .532 & .944 \\
\hline & .582 & .001 & .001 & .001 & .001 \\
\hline \multicolumn{6}{|l|}{$18: 1(n-9)$} \\
\hline 0 & 38.48 & $45.79^{b}$ & $46.78^{b}$ & $47.84^{\mathrm{b}}$ & $48.39^{\mathrm{b}}$ \\
\hline $\mathrm{H}$ & 38.41 & $39.28^{\mathrm{c}}$ & $38.19^{c}$ & $37.76^{\mathrm{c}}$ & $36.90^{c}$ \\
\hline $\mathrm{L}$ & 37.76 & $36.78^{\mathrm{c}}$ & $35.79^{c}$ & $37.00^{c}$ & $36.02^{c}$ \\
\hline $\mathrm{SE}$ & .738 & .837 & .641 & .449 & .907 \\
\hline$P$ & .753 & .001 & .001 & .001 & .001 \\
\hline \multicolumn{6}{|c|}{$16: 1(n-7)+18: 1(n-7)$} \\
\hline $\mathrm{O}$ & 6.31 & 5.30 & 4.78 & $3.81^{\mathrm{c}}$ & 3.58 \\
\hline $\mathrm{H}$ & 7.53 & 5.57 & 5.00 & $4.46^{\mathrm{b}}$ & 3.95 \\
\hline $\mathrm{L}$ & 7.08 & 5.31 & 4.71 & $3.84^{\mathrm{c}}$ & 3.13 \\
\hline $\mathrm{SE}$ & .427 & .269 & .277 & .146 & .272 \\
\hline$P$ & .159 & .733 & .746 & .010 & .120 \\
\hline \multicolumn{6}{|l|}{ Total trans } \\
\hline 0 & .89 & $.76^{\mathrm{c}}$ & $.57^{\mathrm{c}}$ & $.42^{\mathrm{c}}$ & $.41^{\mathrm{c}}$ \\
\hline $\mathrm{H}$ & .85 & $3.57^{\mathrm{b}}$ & $5.71^{\mathrm{b}}$ & $6.39^{b}$ & $6.67^{\mathrm{b}}$ \\
\hline $\mathrm{L}$ & .88 & $.70^{c}$ & $.60^{\mathrm{c}}$ & $.54^{\mathrm{c}}$ & $.45^{\mathrm{c}}$ \\
\hline $\mathrm{SE}$ & .034 & .200 & .155 & .139 & .011 \\
\hline$P$ & .675 & .001 & .001 & .001 & .001 \\
\hline \multicolumn{6}{|l|}{$18: 1(n-9)$ trans } \\
\hline O & .57 & $.58^{\mathrm{c}}$ & $.43^{\mathrm{c}}$ & $.29^{\mathrm{c}}$ & $.30^{\mathrm{c}}$ \\
\hline $\mathrm{H}$ & .54 & $3.12^{\mathrm{b}}$ & $5.06^{\mathrm{b}}$ & $5.66^{\mathrm{b}}$ & $5.88^{b}$ \\
\hline $\mathrm{L}$ & .56 & $.50^{c}$ & $.40^{\mathrm{c}}$ & $.40^{\mathrm{c}}$ & $.34^{\mathrm{c}}$ \\
\hline $\mathrm{SE}$ & .027 & .186 & .144 & .123 & .093 \\
\hline$P$ & .657 & .001 & .001 & .001 & .001 \\
\hline \multicolumn{6}{|l|}{$16: 1(n-7)$ trans } \\
\hline & .13 & $.10^{\mathrm{c}}$ & $.06^{\mathrm{c}}$ & $.04^{\mathrm{c}}$ & $.04^{\mathrm{c}}$ \\
\hline $\mathrm{H}$ & .12 & $.17^{\mathrm{b}}$ & $.19^{\mathrm{b}}$ & $.19^{\mathrm{b}}$ & $.19^{\mathrm{b}}$ \\
\hline $\mathrm{L}$ & .13 & $.09^{\mathrm{c}}$ & $.06^{\mathrm{c}}$ & $.05^{\mathrm{c}}$ & $.04^{\mathrm{c}}$ \\
\hline $\mathrm{SE}$ & .005 & .013 & .006 & .008 & .08 \\
\hline$P$ & .657 & .001 & .001 & .001 & .001 \\
\hline \multicolumn{6}{|l|}{$18: 2(n-6)$ trans } \\
\hline O & .19 & $.08^{\mathrm{c}}$ & $.08^{\mathrm{c}}$ & $.08^{\mathrm{c}}$ & $.07^{\mathrm{c}}$ \\
\hline $\mathrm{H}$ & .19 & $.28^{\mathrm{b}}$ & $.46^{\mathrm{b}}$ & $.54^{\mathrm{b}}$ & $.59^{\mathrm{b}}$ \\
\hline $\mathrm{L}$ & .19 & $.11^{\mathrm{c}}$ & $.13^{\mathrm{c}}$ & $.10^{\mathrm{c}}$ & $.07^{\mathrm{c}}$ \\
\hline $\mathrm{SE}$ & .010 & .008 & .011 & .011 & .010 \\
\hline & .978 & .001 & .001 & .001 & .001 \\
\hline \multicolumn{6}{|l|}{$20: 1(n-9)$} \\
\hline 0 & .76 & .84 & $.82^{\mathrm{b}}$ & .86 & $.97^{\mathrm{b}}$ \\
\hline & & .80 & $.73^{\mathrm{bc}}$ & .72 & $.72^{\mathrm{c}}$ \\
\hline $\mathrm{L}$ & .80 & .72 & $.62^{\mathrm{c}}$ & .68 & $.72^{\mathrm{c}}$ \\
\hline $\mathrm{SE}$ & .030 & .034 & .041 & .057 & .048 \\
\hline$P$ & .399 & .057 & .017 & .074 & .003 \\
\hline
\end{tabular}

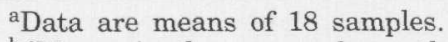

$\mathrm{b}, \mathrm{c}$ Means in the same column that do not have a common superscript are different $(P<.05)$,

$6 \%$ (from 46.19 to $52.45 \%$ ) after d 17 (Figure 2, Eq. 8 ). The daily fractional rate was $13.70 \%$. These results contrast $(P<.001$; Table 4$)$ with those for the $\mathrm{L}$ and $\mathrm{H}$ diets, in which MUFA contents decrease at a monthly rate of $2.40 \%$. These results are basically due to changes in oleic acid contents (Table 6) and coincide with the findings of other studies. For instance, St. John et al. (1987), Miller et al. (1990), and Myer et al. (1992), working with pigs of $100 \mathrm{~kg}$ live weight, also found a higher level of monounsaturation in the backfat of pigs fed a diet with added sunflower oil or canola oil, both rich in oleic acid, than in pigs fed a control diet with no additional fat. Their results for oleic acid contents are similar to ours.

As for 16:1(n-7) (palmitoleic acid) and 18: $1(n-7)$ (Figure 2), both showed a similar decrease in 
EVOLUTION OF FATTY ACID PROFILES OF SWINE BACKFAT

Table 5. (n-3) and (n-6) fatty acids (\%) of backfat samples from swine fed diets containing pomace oil $(\mathrm{O})$, hydrogenated oil $(\mathrm{H})$, and linseed oil $(\mathrm{L})$

\begin{tabular}{|c|c|c|c|c|c|}
\hline \multirow{2}{*}{$\begin{array}{l}\text { Fatty acid and } \\
\text { treatment }^{\mathrm{a}}\end{array}$} & \multicolumn{5}{|c|}{ Day } \\
\hline & 0 & 17 & 31 & 60 & 82 \\
\hline \multicolumn{6}{|l|}{ Total $(n-3)$} \\
\hline 0 & 1.42 & $1.14^{\mathrm{c}}$ & $1.09^{c}$ & $1.07^{\mathrm{c}}$ & $1.17^{\mathrm{c}}$ \\
\hline $\mathrm{H}$ & 1.54 & $1.19^{c}$ & $1.32^{c}$ & $1.92^{\mathrm{c}}$ & $1.96^{c}$ \\
\hline $\mathrm{L}$ & 1.54 & $5.76^{\mathrm{b}}$ & $8.59^{b}$ & $9.20^{\mathrm{b}}$ & $10.58^{b}$ \\
\hline $\mathrm{SE}$ & .081 & .230 & .166 & .404 & .663 \\
\hline$P$ & .477 & .001 & .001 & .001 & .001 \\
\hline \multicolumn{6}{|l|}{$18: 3(n-3)$} \\
\hline $\mathrm{O}$ & 1.08 & $.85^{\mathrm{c}}$ & $.86^{c}$ & $.85^{\mathrm{c}}$ & $.99^{c}$ \\
\hline $\mathrm{H}$ & 1.14 & $.91^{c}$ & $1.04^{c}$ & $1.57^{c}$ & $1.61^{c}$ \\
\hline $\mathrm{L}$ & 1.14 & $4.94^{\mathrm{b}}$ & $7.40^{\mathrm{b}}$ & $7.89^{\mathrm{b}}$ & $9.16^{b}$ \\
\hline SE & .056 & .201 & .148 & .383 & .641 \\
\hline$P$ & .686 & .001 & .001 & .001 & .001 \\
\hline \multicolumn{6}{|c|}{$20: 3(n-3)+20: 5(n-3)+22: 5(n-3)$} \\
\hline 0 & .25 & $.24^{\mathrm{c}}$ & $.19^{c}$ & $.19^{c}$ & $.17^{\mathrm{c}}$ \\
\hline $\mathrm{H}$ & .28 & $.24^{\mathrm{c}}$ & $.24^{\mathrm{c}}$ & $.31^{\mathrm{c}}$ & $.33^{\mathrm{c}}$ \\
\hline $\mathrm{L}$ & .28 & $.73^{\mathrm{b}}$ & $1.13^{\mathrm{b}}$ & $1.29^{\mathrm{b}}$ & $1.40^{\mathrm{b}}$ \\
\hline $\mathrm{SE}$ & .016 & .041 & .026 & .033 & .050 \\
\hline$P$ & .206 & .001 & .001 & .001 & .001 \\
\hline \multicolumn{6}{|l|}{$22: 6(n-3)$} \\
\hline $\mathrm{O}$ & .09 & $.06^{\mathrm{c}}$ & .04 & $.02^{\mathrm{c}}$ & .01 \\
\hline $\mathrm{H}$ & .12 & $.05^{\mathrm{c}}$ & .04 & $.03^{\mathrm{b}}$ & .02 \\
\hline $\mathrm{L}$ & .12 & $.09^{\mathrm{b}}$ & .05 & $.02^{\mathrm{c}}$ & .02 \\
\hline $\mathrm{SE}$ & .016 & .007 & .004 & .001 & .004 \\
\hline$P$ & .390 & .003 & .153 & .001 & .411 \\
\hline \multicolumn{6}{|l|}{ Total $(n-6)$} \\
\hline $\mathrm{O}$ & 19.06 & 14.70 & $13.18^{\mathrm{c}}$ & 11.38 & 9.54 \\
\hline $\mathrm{H}$ & 19.88 & 14.69 & $13.99^{c}$ & 12.40 & 10.18 \\
\hline $\mathrm{L}$ & 20.14 & 15.55 & $15.46^{\mathrm{b}}$ & 12.82 & 10.87 \\
\hline $\mathrm{SE}$ & .674 & .642 & .453 & .453 & .512 \\
\hline$P$ & .517 & .564 & .009 & .077 & .198 \\
\hline \multicolumn{6}{|l|}{$18: 2(n-6)$} \\
\hline $\mathrm{O}$ & 17.93 & 13.82 & $12.48^{\mathrm{c}}$ & 10.71 & 8.95 \\
\hline $\mathrm{H}$ & 18.66 & 17.72 & $13.20^{\mathrm{bc}}$ & 11.70 & 9.60 \\
\hline $\mathrm{L}$ & 18.94 & 14.60 & $14.38^{\mathrm{b}}$ & 12.02 & 10.09 \\
\hline $\mathrm{SE}$ & .654 & .582 & .441 & .436 & .491 \\
\hline$P$ & .221 & .521 & .026 & .087 & .267 \\
\hline \multicolumn{6}{|c|}{$20: 2(n-6)+20: 3(n-6)+20: 4(n-6)$} \\
\hline $\mathrm{O}$ & .87 & .67 & $.55^{\mathrm{c}}$ & .54 & .47 \\
\hline $\mathrm{H}$ & .86 & .76 & $.59^{c}$ & .52 & .42 \\
\hline $\mathrm{L}$ & .89 & .67 & $.76^{\mathrm{b}}$ & .59 & .53 \\
\hline $\mathrm{SE}$ & .028 & .006 & .022 & .022 & .031 \\
\hline$P$ & .780 & .474 & .001 & .084 & .074 \\
\hline \multicolumn{6}{|l|}{$22: 4(n-6)$} \\
\hline $\mathrm{O}$ & .07 & .06 & $.05^{\mathrm{c}}$ & $.05^{\mathrm{b}}$ & $.05^{\mathrm{b}}$ \\
\hline $\mathrm{H}$ & .11 & .06 & $.07^{\mathrm{b}}$ & $.06^{\mathrm{b}}$ & $.05^{b}$ \\
\hline $\mathrm{L}$ & .09 & .06 & $.05^{\mathrm{c}}$ & $.03^{c}$ & $.02^{\mathrm{c}}$ \\
\hline $\mathrm{SE}$ & .010 & .001 & .004 & .003 & .004 \\
\hline$P$ & .544 & .968 & .014 & .001 & .001 \\
\hline
\end{tabular}

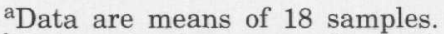

b,c Means in the same column that do not have a common superscript are different $(P<.05)$.

all diets. The adjusted function (Table 6, Eq. 10) for these two fatty acids displayed a negative slope $(-.04)$, at a monthly rate of $1.20 \%$. At the end of the trial, pigs fed the $O$ diet also had slightly higher values for $20: 1(n-9)$ than pigs fed the other diets $(O$, .97 vs $\mathrm{H}, .72$ and $\mathrm{L}, .72 \% ; P<.05)$, due to the higher content of oleic acid, its precursor, in the diet.
The following can therefore be concluded: 1 ) in our working conditions, Eq. 8 (Table 6 ) shows that $95 \%$ of the possible incorporation of total MUFA (53.08\%) can be reached by d 17 and 2) fat tissue contents of these fatty acids showed a tendency to decrease in diets $\mathrm{L}$ and $\mathrm{H}$, which had lower MUFA percentages than $\mathrm{O}$. Even though oleic acid can also have an 
Table 6. Regression equations of the saturated and cis-monounsaturated fatty acid evolution from swine fed diets containing pomace oil $(\mathrm{O})$, hydrogenated oil $(\mathrm{H})$, and linseed oil $(\mathrm{L})$

\begin{tabular}{|c|c|c|c|c|c|c|}
\hline Fatty acid & Treatment $^{\mathrm{a}}$ & Equation $^{\mathrm{b}}$ & $P$ & $\mathrm{R}^{2}$ & $\mathrm{RSD}^{\mathrm{c}}$ & $\begin{array}{c}\text { Significance of } \\
\text { slopes comparison }\end{array}$ \\
\hline Total SFA $17 \mathrm{~d}^{\mathrm{b}}$ & $\begin{array}{l}\mathrm{O} \\
\mathrm{H}, \mathrm{L}\end{array}$ & $\begin{array}{l}(1) \mathrm{y}=29.96+.07 * \mathrm{t} \\
(2) \mathrm{y}=32.64+.06 * \mathrm{t}\end{array}$ & $\begin{array}{l}.001 \\
.0001\end{array}$ & $\begin{array}{l}.41 \\
.33\end{array}$ & $\begin{array}{l}2.17 \\
2.30\end{array}$ & .07 \\
\hline $16: 0$ & $\mathrm{O}, \mathrm{H}, \mathrm{L}$ & $(3) y=20.81+.014 * t$ & .0006 & .10 & 1.27 & \\
\hline $18: 017 \mathrm{~d}$ & $\begin{array}{l}\mathrm{O} \\
\mathrm{H}, \mathrm{L}\end{array}$ & $\begin{array}{l}(4) \mathrm{y}=7.95+.05 * \mathrm{t} \\
(5) \mathrm{y}=9.16+.06 * \mathrm{t}\end{array}$ & $\begin{array}{l}.0005 \\
.0001\end{array}$ & $\begin{array}{l}.44 \\
.58\end{array}$ & $\begin{array}{l}1.27 \\
1.32\end{array}$ & .26 \\
\hline $\mathrm{SFAm}^{\mathrm{e}}$ & $\mathrm{O}, \mathrm{H}, \mathrm{L}$ & (6) $y=2.22-.008 * t$ & .0001 & .60 & .193 & \\
\hline $20: 0$ & $\mathrm{O}, \mathrm{H}, \mathrm{L}$ & $(7) y=.12+.001 * t$ & .0001 & .58 & .033 & \\
\hline Total MUFA & $\begin{array}{l}\mathrm{O} \\
\mathrm{H}, \mathrm{L}\end{array}$ & $\begin{array}{l}(8) y=53.08-6.89 * \mathrm{e}^{(-.137 * \mathrm{t})} \\
(9) \mathrm{y}=45.75-.08 * \mathrm{t}\end{array}$ & $\begin{array}{l}.001 \\
.001\end{array}$ & $\begin{array}{l}.65 \\
.47\end{array}$ & $\begin{array}{l}2.119 \\
2.352\end{array}$ & \\
\hline $18: 1(n-9) c$ & $\begin{array}{l}\mathrm{O} \\
\mathrm{H}, \mathrm{L}\end{array}$ & $\begin{array}{l}\mathrm{y}=48.04-9.53 * \mathrm{e}^{(-.078 * t)} \\
\mathrm{y}=37.97-.027 * t\end{array}$ & $\begin{array}{l}.001 \\
.001\end{array}$ & $\begin{array}{l}.83 \\
.15\end{array}$ & $\begin{array}{l}1.750 \\
1.892\end{array}$ & \\
\hline $\begin{array}{l}16: 1(n-7) c+18: 1(n-7) c \\
20: 1(n-9) c\end{array}$ & $\begin{array}{l}\mathrm{O}, \mathrm{H}, \mathrm{L} \\
\mathrm{O} \\
\mathrm{H}, \mathrm{L}\end{array}$ & $\begin{array}{l}(10) \mathrm{y}=6.36-.040 * \mathrm{t} \\
(11) \mathrm{y}=.77+.002 * \mathrm{t} \\
(12) \mathrm{y}=.77-.001 * \mathrm{t}\end{array}$ & $\begin{array}{l}.001 \\
.009 \\
.136\end{array}$ & $\begin{array}{l}.68 \\
.23 \\
.08\end{array}$ & $\begin{array}{l}.816 \\
.113 \\
.109\end{array}$ & \\
\hline
\end{tabular}

${ }^{a} n=90$ ( 6 samples $* 3$ treatments $* 5$ times).

${ }^{\mathrm{b}}$ Corresponding graphics in Figures 1 and 2.

${ }^{\mathrm{C}} \mathrm{RSD}=$ residual SD.

${ }^{\mathrm{d} E q u a t i o n s}$ calculated starting trial d 17 .

${ }^{\mathrm{e}} 10: 0+12: 0+14: 0+15: 0+17: 0$.

endogenous origin, the percentage analysis of data shows an inversely proportional relationship between the incorporation of oleic acid and of other fatty acids. Camoes et al. (1995) found the percentage increase in PUFA, exclusively due to the diet, paralleled decrease in oleic acid contents.

Trans-Monounsaturated Fatty Acids. The evolution of contents in total trans-monounsaturated fatty acids (TFA) differed widely depending on the diet (Figure 3 ). In our conditions, pigs fed the $\mathrm{H}$ diet had a daily fractional rate of $4.20 \%$ for trans-fatty acids. Incorporation rates were greater $(4.49 \%)$ at $31 \mathrm{~d}$ (i.e., $73 \%$ of the maximum). Later, the increase became much slower and reached $5.67 \%$ at 60 trial d (i.e., $92 \%$ of the maximum). Pigs fed the $\mathrm{O}$ or the $\mathrm{L}$ diets with very small trans-fatty acids content showed a slow, linear decrease (Table 7, Eq. 14). This evolution reflects changes in contents of the main trans-fatty acid (18: $1[n-9] \mathrm{t})$ and minor fatty acids, such as 16 : $1(n-7) \mathrm{t}$ and the trans isomers of linolenic acid.

From these results it can be inferred that transfatty acid content in pork backfat can be increased, and that such an increase is only significant when diets have correspondingly high trans-fatty acid content, as is the case with essential fatty acids. No studies have been published on the level of trans-fatty acid incorporation in pigs. In human beings, however, there seem to be no important differences between digestion, absorption, and transport of trans-fatty acids and of their cis isomers (Emken, 1989). The incorporation into body tissues should in principle be similar to that in pigs. This is important, because dietary trans-fatty acids incorporating into the tissues

Table 7. Regression equation of the trans-monounsaturated fatty acid evolution from swine fed diets containing pomace oil $(\mathrm{O})$, hydrogenated oil $(\mathrm{H})$, and linseed oil (L)

\begin{tabular}{llllll}
\hline \hline Fatty acid & $\begin{array}{l}\text { Treat- } \\
\text { ment }^{\mathrm{a}}\end{array}$ & Equation $^{\mathrm{b}}$ & $P$ & $\mathrm{R}^{2}$ & RSD $^{\mathrm{c}}$ \\
\hline Total trans & $\mathrm{H}$ & $(13) \mathrm{y}=6.94-6.17 * \mathrm{e}^{(-.042 * \mathrm{t})}$ & .001 & .94 & .575 \\
& $\mathrm{O}, \mathrm{L}$ & $(14) \mathrm{y}=.82-.006 * \mathrm{t}$ & .001 & .50 & .173 \\
$18: 1(n-9)$ trans & $\mathrm{H}$ & $\left.\mathrm{y}=6.11-5.64 * \mathrm{e}^{-.044} * \mathrm{t}\right)$ & .001 & .94 & .527 \\
& $\mathrm{O}, \mathrm{L}$ & $\mathrm{y}=.55-.004 * \mathrm{t}$ & .001 & .32 & .152 \\
$16: 1(n-7)$ trans & $\mathrm{H}$ & $\mathrm{y}=.19-.073 * \mathrm{e}^{(-.069 * \mathrm{t})}$ & .001 & .57 & .03 \\
& $\mathrm{O}, \mathrm{L}$ & $\mathrm{y}=.11-.001 * \mathrm{t}$ & .001 & .71 & .020 \\
$18: 2(n-6)$ trans & $\mathrm{H}$ & $\mathrm{y}=.71-.53 * \mathrm{e}^{(-.020 * \mathrm{t})}$ & .001 & .93 & .045 \\
& $\mathrm{O}, \mathrm{L}$ & $\mathrm{y}=.15-.001 * \mathrm{t}$ & .001 & .49 & .038 \\
\hline
\end{tabular}

${ }^{a} \mathrm{n}=90$ (6 samples $* 3$ treatments $* 5$ times).

$\mathrm{b}(13)$ and (14): Corresponding graphics in Figure 3.

${ }^{\mathrm{c}} \mathrm{RSD}=$ residual SD. 
Table 8. Regression equations of the $(n-3)$ and $(n-6)$ fatty acid evolution from swine fed diets containing pomace oil $(\mathrm{O})$, hydrogenated oil $(\mathrm{H})$, and linseed oil (L)

\begin{tabular}{|c|c|c|c|c|c|}
\hline \multirow[t]{2}{*}{ Total $(n-3)$} & $\mathrm{L}$ & $(15) y=10.57-9.07 * \mathrm{e}^{(-.041 * t)}$ & .001 & .86 & 1.290 \\
\hline & $\mathrm{O}, \mathrm{H}$ & $(16) y=1.27-.003 * t$ & .150 & .04 & .379 \\
\hline $18: 3(n-3)$ & $\mathrm{O}, \mathrm{H}$ & $y=.94+.004 * t$ & .017 & .10 & .312 \\
\hline \multirow[t]{2}{*}{$20: 3(n-3)+20: 5(n-3)+22: 5(n-3)$} & $\mathrm{L}$ & $(17) \mathrm{y}=1.47-1.20 * \mathrm{e}^{(-.034 * \mathrm{t})}$ & .001 & .92 & .131 \\
\hline & $\mathrm{O}, \mathrm{H}$ & $(18) \mathrm{y}=.24-.00002 * \mathrm{t}$ & .150 & .04 & .379 \\
\hline $18: 2(n-6)$ & $\mathrm{O}, \mathrm{H}, \mathrm{L}$ & $\mathrm{y}=17.09-.094 * t$ & .001 & .74 & 1.656 \\
\hline \multirow[t]{2}{*}{$18: 3(n-6)$} & $\mathrm{O}, \mathrm{H}$ & $\mathrm{y}=.041-.0003 * \mathrm{t}$ & .001 & .24 & .015 \\
\hline & $\mathrm{L}$ & $y=.081+.0014 * t$ & .001 & .58 & .036 \\
\hline \multirow[t]{2}{*}{$22: 4(n-6)$} & $\mathrm{O}, \mathrm{H}$ & $(21) \mathrm{y}=.078-.0004 * \mathrm{t}$ & .001 & .28 & .021 \\
\hline & $\mathrm{L}$ & $(22) y=.084-.0089 * t$ & .001 & .68 & .018 \\
\hline $20: 2(n-6)+20: 3(n-6)+20: 4(n-6)$ & $\mathrm{O}, \mathrm{H}, \mathrm{L}$ & $(23) y=.973-.005 * t$ & .001 & .61 & .125 \\
\hline
\end{tabular}

$\mathrm{a}_{\mathrm{n}}=90$ ( 6 samples $* 3$ treatments $* 5$ times $)$

$\mathrm{b}(15)-(23)$ : Corresponding graphics in Figures 4 and 5.

${ }^{\mathrm{c}} \mathrm{RSD}=$ residual $\mathrm{SD}$.

have metabolic effects similar to those of saturated fatty acids (Nestel et al., 1992).

Polyunsaturated Fatty Acids. The proportions of ( $n$ 3 ) contents in pigs fed the $\mathrm{L}$ diet were different $(P<$ .001) from the percentages in pigs fed the $H$ and $O$ diets. Pigs fed the $\mathrm{L}$ diet had a daily fractional rate of $4 \%$ in the first $31 \mathrm{~d}$, reflecting the increase in linolenic acid (Table 8, Eq. 15 and 16). Incorporation rates were more important during the trial's first month, reaching $6.53 \%$, which is $72 \%$ of the maximum of 9.07\%. Later, incorporations became slower; at $60 \mathrm{~d}$, $8.30 \%$ had accumulated, which represents $92 \%$ of the maximum $(n-3)$ contents.

In Romans et al. (1995b), pigs were fed a diet with $15 \%$ linseeds, which provided $35 \%$ of linolenic acid, and slaughtered after $7,14,21$, and $28 \mathrm{~d}$. Their results show that the longer the treatment, the higher the content of $(n-3)$ and 18:3 in the backfat; at $7 \mathrm{~d}$, it was $.72 \%$, and at $28 \mathrm{~d}$ it had become $2.7 \%$. Even though proportions in Romans et al. (1995b) were lower than ours, they used a diet with a larger crude fat supplement $(7.8$ vs $6 \%)$ and higher content of 18 : $3(n-3)(35.00$ vs $25.70 \%)$. Two reasons might help explain these differences. First, in Romans et al. $(1995 \mathrm{~b})$, pigs had an average live weight of $114 \mathrm{~kg}$ at the start of the trial, and by then the fat tissue has developed; causing changes in its composition is more difficult, because incorporation of fatty acids from the diet is much slower. Second, the absorption efficiency of $18: 3(n-3)$ in the small intestine may depend on the use of linseeds vs linseed oil as the $(n-3)$ source in the diet. Given that linseed oil has a higher content of triglyceride with an absorption rate higher than $95 \%$, it is possible that digestion and absorption of linolenic acid from linseeds is not as efficient as absorption of linolenic acid from linseed oil (Nelson and Ackman, 1988). Camoes et al. (1995) focussed on the incorpo- ration of linoleic acid (exclusively from dietary sources) into backfat tissue and observed that a constant supplement of linoleic acid in the diet caused a linear increase in the percentage of incorporation into the fat tissue. They also observed that when the diet is changed to a more saturated one, the percentage of linoleic acid in the backfat of pigs decreases rapidly. When the diet is not supplemented with a high level of essential fatty acids, their presence in the backfat is not very significant (Figures 4 and 5 ). In our case, contents of $(n-3)$ and $18: 3(n-3)$ in pigs fed the $\mathrm{O}$ and $\mathrm{H}$ diets remained nearly constant throughout the trial (Table 8), and they had modest percentages of total $(n-3)(\mathrm{O}, 1.17$ and $\mathrm{H}, 1.96 \%)$ and $18: 3(n-3)(\mathrm{O}, .99$ and $\mathrm{H}, 1.61 \%$; Table 5$)$. Our figures show that $25.79 \%$ of linolenic acid in dietary fat results in $7.40 \%$ in the backfat at $d 31$. Incorporations were slower afterward and reached $9.16 \%$ at the end of the trial. Despite the difference between the maximum contents of TFA $(6.94 \%)$ and of $(n-3)$ fatty acids (10.57), daily incorporations were nearly the same $(4 \%)$.

Linoleic acid and total ( $n-6)$ percentages decreased at a monthly rate of $3 \%$, due to the low content of these essential fatty acids in the diets. At the end of the trial, total $(n-6)$ differences among diets were very small $(\mathrm{O}, 9.54 ; \mathrm{H}, 10.18$; and $\mathrm{L}, 10.87 \% ; P>.05$; Table 5). Cunnane et al. (1990) and Cherian and Sim (1995) used diets with low contents of these fatty acids and also observed that backfat content percentages were lower than the corresponding diet percentages.

For $(n-3)$ derived acids $(20: 3[n-3]+20: 5[n-3]+22$ : $5[n-3]$, pigs fed the $\mathrm{L}$ diet reached slightly higher contents $(P<.001)$ than the rest $(\mathrm{L}, 1.40$ vs $\mathrm{O}, .17$ and $H, .33 \%$, and the same happened to linolenic acid, which is their precursor. These derivatives 
incorporated into the backfat at a daily fractional rate of $3 \%$, although rates were higher in the first $4 \mathrm{wk}$. Pigs on $\mathrm{O}$ or $\mathrm{H}$ diets did not have any significant evolution throughout the period $(P>.05)$. The evolution of $22: 6(n-3)$ was the same in all diets, and no differences were observed in any biopsy (Table 8 , Eq. 19).

Irie and Sakimoto (1992) fed pigs (84 $\mathrm{kg}$ live weight) with diets with 2,4 , and $6 \%$ added fish oil for $4 \mathrm{wk}$ and observed that the highest rise in eicosapentaenoic acid ( EPA) and docosahexaenoic acid (DHA) took place in the first $2 \mathrm{wk}$, and at the end of the month incorporation rates were much slower. Diets with $6 \%$ added fish oil had higher contents of EPA $(10.8 \%), 22: 5(n-3)(1.6 \%)$, and DHA (4.4\%), much higher than in our diets, and caused the highest levels of $20: 5(n-3)(1.16 \%), 22: 5(n-3)(1.18 \%)$, and 22 : $6(n-3)(1.28 \%)$ in the carcass.

Minor $(n-6)$ derivatives $(20: 2[n-6]+20: 3[n-6]+20$ : $4[n-6]$ ) had a similar minimal decrease (Table 8, Eq. 23 ). In the case of docosatetraenoic acid, the decrease was slightly more important for pigs fed the $\mathrm{L}$ diet. The $(n-3)$ and $(n-6)$ fatty acid derivatives, such as eicosapentaenoic and arachidonic acids, share the same processes of metabolic synthesis and, crucially, the enzyme $\Delta-6$ desaturase (Brenner, 1971). Thus, in pigs fed the ( $n-3)$-rich diet, the $\Delta-6$ desaturase may focus on the synthesis of $(n-3)$ derivatives from $18: 3(n-3)$, instead of on the synthesis of $(n-6)$ derivatives from 18:2(n-6). From these results it can be concluded that adding linolenic acid to the diet effectively increases ( $n-3)$ derivative content, but not DHA. In any case, the improvement is not as important as when the diet is supplemented with fish oil. However, the decrease in $(n-6)$ derivatives is probably due to low content of linoleic acid (their precursor) in the diet. Pigs fed the $L$ diet had the lowest percentages, probably because $(n-6)$ derivatives have to compete with $(n-3)$ derivatives.

\section{Implications}

Whereas several authors have documented the possibility of modifying the lipid deposits in the carcass, the present work focuses on the incorporation rates of fatty acids into backfat and makes it possible to estimate the minimum time needed to cause noticeable changes in the tissues. In our working conditions, monounsaturated fatty acids from endogenous synthesis and dietary sources reached 95\% of the maximum level $(53.08 \%)$ throughout the experimental period by $\mathrm{d} 17$ of the trial. In contrast, trans-fatty acids and (n-3) fatty acids, which originate only in the diet, reached $70 \%$ at $\mathrm{d} 30$ and $95 \%$ of the maximum level at d $60(10.57 \%$ [n-3]; $6.94 \%$ trans). These patterns reflect the incorporation levels of the main dietary fatty acids: oleic, linolenic, and elaidic acids.

\section{Literature Cited}

AOAC. 1990. Official Methods of Analysis (15th Ed.). Association of Official Analytical Chemists, Arlington, VA.

Brenner, R. R. 1971. The desaturation steps in the animal biosynthesis of polyunsaturated fatty acids. Lipids 6:567-575.

Camoes, J., J. Mourot, M. Kouba, P. Cherot, and A. Mounier. 1995. Effets de régimes à teneurs variables en acide linoléique sur les caractéristiques des tissus adipeux. Journ. Rech. Porcine France 27:291-296.

Cava, R., J. Ruiz, C. López-Bote, L. Martín, C. Garcia, J. Ventanas, and T. Antequera. 1997. Influence of finishing diet on fatty acid profiles of intramuscular lipids triglycerides and phospholipids in muscles of Iberian pig. Meat Sci, 2:263-270.

Cherian, G. Y., and J. S. Sim. 1995. Dietary a-linolenic acid alters the fatty acid composition of lipid classes in swine tissues. J. Agric. Food Chem. 43:2911-2916.

Cole, H. H. (Ed.). 1973. Introduction to Livestock Production. W. H. Freeman \& Co., San Francisco, CA.

Cunnane, S. C., P. A. Spitt, S. Ganguli, and J. Armstrong. 1990. Raised OMEGA 3 fatty levels in pigs fed flax. Can. J. Anim. Sci. 70:251-254.

Emken, E. A., R. O. Adolf, W. K. Rohwedder, and R. M. Gulley. 1989. Incorporation of trans-8 and cis-8-octadecenoic acid isomers in human plasma and lipoprotein lipids. Lipids 15: 864-871.

Folch, J., M. Lees, and G. N. Sloan-Stanley. 1957. A simple method for the isolation and purification of total lipides from animal tissues. J. Biol. Chem. 226:497-509.

Guardiola, F., R. Codony, M. Rafecas, J. Boatella, A. Lopez. 1994. Fatty acid composition and nutritional value of fresh eggs from large- and small-scale farms. J. Food Compos. Anal. 7:171-188.

Hertzman, C., L. Göransson, and H. Rudérus. 1988. Influence of fishmeal, rape-seed, and rape-seed meal in feed on the fatty acid composition and storage stability of porcine body fat. Meat Sci. 23:37-53.

Irie, M., and M. Sakimoto. 1992. Fat characteristics of pigs fed fish oil containing eicosapentaenoic and docosahexaenoic acids. J. Anim. Sci. 70:470-477.

Klingenberg, I. L., D. A. Knabe, and S. B. Smith. 1995. Lipid metabolism in pigs fed beef tallow or high-oleic acid sunflower oil. Comp. Biochem. Biophys. 110:183-192

Koch, D. E., A. M. Pearson, W. T. Magee, J. A. Hoefer, and B. S. Schweigert. 1968. Effect of diet on the fatty acid composition of pork fat. J. Anim. Sci. 27:360-365.

Leszcynski, D. E., J. Pikul, R. A. Easter, F. K. McKeith, D. G. McLaren, J. Novakofski, P. J. Bechtel, and D. E. Jewell. 1992. Characterization of lipid in loin and bacon from finishing pigs fed full-fat soybeans or tallow. J. Anim. Sci. 70:2175-2181.

Miller, M. F., S. D. Shackelford, K. D. Hayden, and J. O. Reagan. 1990. Determination of the alteration in fatty acid profiles, sensory characteristics and carcass traits of swine fed elevated levels of monounsaturated fats in the diet. J. Anim. Sci. 68: 1624-1631

Myer, R. O., D. D. Johnson, D. A. Knauft, D. W. Gorbet, J. H. Brendemuhl, and W. R. Walker. 1992. Effect of feeding higholeic-acid peanuts to growing-finishing swine on resulting carcass fatty acid profile and on carcass and meat quality characteristics. J. Anim. Sci. 70:3734-3741.

Nelson, G. J., and R. G. Ackman. 1988. Absorption and transport of fat in mammals with emphasis on $(n-3)$ polyunsaturated fatty acids. Lipids 23:1005-1014.

Nestel, P. J., M. Noakes, and B. Belling. 1992. Plasma lipoprotein lipids and $\operatorname{lp}(\mathrm{a})$ changes with substitution of elaidic acid for oleic in the diet. J. Lipid Res. 33:1029-1036.

NRC. 1988. Nutrient Requirements of Swine (9th Ed.). National Academy Press, Washington, DC.

Romans, J. R., R. C. Johnson, D. M. Wulf, G. W. Libal, and W. J. Costello. 1995a. Effects of ground flaxseed in swine diets on pig 
performance and on physical and sensory characteristics and omega-3 fatty acid content of pork: I. Dietary level of flaxseed. J. Anim. Sci. 73:1982-1986.

Romans, J. R., D. M. Wulf, R. C. Johnson, G. W. Libal, and W. J. Costello. 1995b. Effects of ground flaxseed in swine diets on pig performance and on physical and sensory characteristics and omega-3 fatty acid content of pork: II. Duration of $15 \%$ dietary flaxseed. J. Anim. Sci. 73:1987-1999.

SAS. 1994. SAS User's Guide: Statistics. SAS Inst. Inc., Cary, NC. St. John, L. C., C. R. Young, D. A. Knabe, L. D. Thompson, G. T.
Schelling, S. M. Grundy, and S. B. Smith. 1987. Fatty acid profiles and sensory and carcass traits of tissues from steers and swine fed an elevated monounsaturated fat diet. J. Anim. Sci. 64:1441-1447.

Waters, K. M., and J. M. Ntambi. 1996. Polyunsaturated fatty acids inhibit hepatic stearoyl-CoA desaturase-1 gene in diabetic mice. Lipids 31:S33-S36.

Wood, J. D. 1984. Fat deposition and the quality of fat tissue in meat animals. In: J. Wiseman (Ed.) Fats in Animal Nutrition. pp 407-435. Butterworths, London. 